Отримано: 23 вересня 2018 р.

Прорецензовано: 5 жовтня 2018 р.

Прийнято до друку: 6 жовтня 2018 р.

e-mail: sevschool@yandex.ua

DOI: $10.25264 / 2519-2558-2018-3(71)-19-22$
Samoylenko Nataliia. What do you need in 21 century to develop in order to improve? Hayкові записки Наиіонального університету «Острозька академія»: серія "Філологія». Острог : Вид-во НаУОА, 2018. Вип. 3(71), вересень. С. 19-22.

\title{
WHAT DO YOU NEED IN 21 CENTURY TO DEVELOP IN ORDER TO IMPROVE?
}

The article reveals the problem of professional online tutor preparation and the opportunities for implementation of online education for improvement of higher pedagogical education in the foreign language teaching process. The author highlights teacher's skills in English language teaching, peculiarities and opportunities for virtual education, describes necessary skills for providing educational online course, advantages of online learning for learning languages.

The article introduces the research of using online platform resources for undergraduate students' language learning; undergraduate students' online learning experience is described. The role of students' digital skills and new trends of online education implementation in the foreign language teaching process in a higher educational institution are highlighted. The goal of this study was to identify whether the use of online platforms in English language learning process has positive response on students' English language skills. The author observes and compares the role of a teacher and the learner in online learning, developing process of new skills and competences and challenges and focuses on teaching online and teaching face-to-face different features. The key skills for online teacher were summarized. The impact of online platform resources for supporting students' thinking about their language learning; helping them to understand the aim of language learning and teaching was pointed out.

Key words: undergraduate student of humanities, professional preparation, online education, online course, online platform resources, students'skills, higher pedagogical educational institution.

\section{Наталія Борисівна Самойленко,}

Севастопольский державний університет

\section{НАВИКИ 21 СТОРІЧЧЯ: ВИКЛИКИ, РОЗВИТОК, ВДОСКОНАЛЕННЯ}

Стаття присвячена проблемі підготовки професійного онлайн-викладача. Автор аналізує особливості та можливості віртуального навчання, узагальнює необхідні навики і уміння викладача для ведення навчального онлайн курсу. У статті представлено дослідження щуодо використання ресурсів онлайн платформ для організації навчання іноземній мові магістрантів; описано досвід онлайн навчання магістрантів. Відмічено роль володіння студентами иифровими уміннями та нові тендениії впровадження онлайн навчання в прочесі викладання іноземної мови у вищому навчальному закладі.

Ключові слова: магістрант гуманітарних спеціальностей, професійна підготовка, онлайн освіта, онлайн курс, ресурси онлайн платформ, навички студентів, вищий педагогічний навчальний заклад.

\section{Наталья Борисовна Самойленко,}

Севастопольский государственный университет

\section{НАВЫКИ 21 СТОЛЕТИЯ: ВЫЗОВЫ, РАЗВИТИЕ, СОВЕРШЕНСТВОВАНИЕ}

Статья посвящена проблеме подготовки профессионального онлайн-преподавателя. Автор анализирует особенности и возможности виртуального обучения, обобщает необходимые навыки и умения преподавателя для ведения учебного онлайн курcа. В статье представлено исследование об использовании ресурсов онлайн платформ для организачии обучения иностранному языку магистрантов; описан опыт онлайн обучения магистрантов. Отмечено роль владения магистрантами иифровыми умениями и новые тенденци внедрения онлайн обучения в процессе преподавания иностранного языка в высшем образовательном учреждении.

Key words: магистрант гуманитарных спеииальностей, профессиональная подготовка, онлайн образование, онлайн курс, ресурсы онлайн платформ, навыки студентов, высшее педагогическое учебное заведение.

Introduction. At present there are different kinds of English, which is taught at all educational levels in higher education. But what kind of English do the students need and use in their lives outside the classroom? As professor Jenkins J. has mentioned, "in Finland, the English language curriculum 'from the 1940s to the present day' has focused on 'the native-speaker ideal', curricula began to refer to the international usefulness and lingua franca function of English from the 1960s and American English was introduced in the 1970s and given equal status with British» [11, p. 45].

Problem statement. The role of 21 century teacher has changed. The teacher needs some new skills, such as: be multilingual and multicultural, know their students' language and understand the educational, social and cultural contexts in which they are working; be aware of English changes and its role in the community and its influence on local languages; be able to evaluate ELT materials.

Research questions. For some years ELF scholars have been observing some changes in higher education. It is globalised. Many universities around the world are described as 'international'. It is very important to focus on the cultural and linguistic implications [14]. In recent researches we have mentioned the role of English as the global lingua franca [4], and as a medium instruction (EMI) in the education process. However, when the globalisation and internationalisation of higher education are discussed, the role of English language in higher education has not discussed enough [12].

Methodology. The problem of professional online tutor preparation is very relevant. We analyzed the opportunities for implementation of online education for improvement of higher pedagogical education in the foreign language teaching process. We would 
like to describe the opportunities for virtual education and communication. It is obviously necessary to generalize today's students' skills for providing education online course.

We conducted a research on the use of online platforms in English language class on a group of the students in a higher educational institution and discovered that it increased students' level of engagement in their autonomous learning [2].

Findings. The CEFR introduces the concept of mediation [6]. Mediation language activities, (re)processing an existing text, occupy an important place in the normal linguistic functioning of our societies [8].There's been a massive increase in the use of technology in the use of English globally. Today technology has an impact on language learning process and provides new ways of teaching and learning: video the students interacting in groups or working on a monologue or story; get students to record podcasts and audio files and to develop their written work in blogs and wikis [1;3]. We analyze the last researches and present teacher's skills in English language teaching in table 1.

Teacher's skills in English language teaching

\begin{tabular}{|c|l|l|l|}
\hline № & \multicolumn{1}{|c|}{ Researcher } & \multicolumn{1}{|c|}{ Teacher's skills } & \multicolumn{1}{c|}{ Reasons } \\
\hline 1 & $\begin{array}{l}\text { A. Cogo, } \\
\text { M. Dewey } \\
\text { [7, p. 170] }\end{array}$ & $\begin{array}{l}\text { - To incorporate the global diversity of English into the } \\
\text { curriculum rather than focusing exclusively on native } \\
\text { English; }\end{array}$ & $\begin{array}{l}\text { Global diversity of English; } \\
\text { effective and successful intercultural } \\
\text { communication. }\end{array}$ \\
\hline $\begin{array}{l}\text { B. Seidlho-fer } \\
\text { [16, p. 197]. }\end{array}$ & $\begin{array}{l}\text { To set realistic objectives that are attainable and more } \\
\text { closely correspond to the needs of the majority of users } \\
\text { of English; } \\
\text { to focus on communicative function and evaluating } \\
\text { forms in terms of their functional effectiveness. }\end{array}$ & $\begin{array}{l}\text { • Communicative use of language; } \\
\text { descriptions of ELF should not directly } \\
\text { determine what language is taught }- \text { this } \\
\text { should remain a local decision [16, p. 199]. }\end{array}$ \\
\hline 3 & $\begin{array}{l}\text { Q. Wen } \\
\text { [20, p. 372]. }\end{array}$ & $\begin{array}{l}\text { To analyse and teach English linguistically, culturally, } \\
\text { pragmatically; }\end{array}$ & $\begin{array}{l}\text { Pedagogical framework for an ELF-informed } \\
\text { approach to the teaching of English. }\end{array}$ \\
\hline $\begin{array}{l}\text { W. Baker } \\
\text { [5, p. 66]: }\end{array}$ & $\begin{array}{l}\text { To raise awareness in an English language classroom } \\
\text { for intercultural communication: } \\
\text { to organize communicative practices related both to } \\
\text { specific cultures and also as emergent and hybrid in } \\
\text { intercultural communication; }\end{array}$ & $\begin{array}{l}\text { Concept «cultural awareness» and its role in } \\
\text { using ELF - developing an understanding of } \\
\text { differences between } \\
\text { one’s own and another culture. }\end{array}$ \\
\hline
\end{tabular}

There are many ways by which teachers can become actively involved in the learning process. Technology influence on language learning process, new ways of teaching and learning. On-line professional training course on leading on-line platforms is an up-today trend in education [9].

Participating in different online courses we are looking for information answering some relevant questions: what does it mean teaching English online?; who might the learners in an online lesson be? why become an online teacher?; is it better to work for a company or for yourself?; what equipment, tools and resources do you need to get started?; what key skills do you need as an online teacher? [19].

We highlight advantages of online learning for learning languages:

1) the online learning flexibility for students' learning languages (they shape their learning, use necessary resources;

2) learners can achieve their different levels in speaking, reading, writing, and in terms of their level of grammar and vocabulary in terms of their level of grammar and vocabulary;

3) learners choose the resources, creating a level of individualisation and their own learning way;

4) psychological challenge: language learners communicate skills in face-to-face environment sometimes is out of confidence. In online space they have time and can think about their responses;

5) learners can set up conversations online with native speakers through closed networks, set up by university.

Having the practice of being an online learners, we feel able to ask for tutor help, technical support or about the course content, to be engaged in the discussions as you need. At the beginning of a course we are only observers, listening, reading the discussions without responds. Taking part in the discussions is very important, because you become motivated, learn much from the course participants.

There are some examples of the online learners' impressions about their experiences:

1) focus on pedagogy and methodology and things: the tutors uploaded the reading list, told you that you had to read this article from this journal, or from this book, then there were forum discussions every week that were compulsory, you had to participate in them;

2) there was a different kind of activity: to collaborate with someone to post a forum post, you read, you do your forum discussion, and then you use all that information in your assignments for the end of the semester;

3) I could do it wherever I was and fit it in with the work schedule;

4) the biggest challenge is time management and the amount of dedication you have to have to it: as a university learner you are talking about the deadline with the people and you have constant news about;

5) the flexibility was incredible: I could do it wherever I was in the world without any access problems [17].

In our practice we use the online platforms for students' autonomous learning and language learning achievement presenting and assessing students' skills. On-line professional training courses on leading on-line platforms are up-today trend in education. There are on-line courses for students and teachers on leading on-line platform «Future Learn» for 2017-2018 yy.: «Research Writing: How to Do a Literature Review» - learn how to write a strong literature review with this course designed for research students, at any level, in any discipline; «Teaching for Success: Lessons and Teaching»-look at lessons, courses and resources with this continuing professional development course for English language teachers [18].

In our practice we use the Language Portfolio (LP) in which learners record their language learning and cultural experiences at educational and or outside educational institutions [2]. Being a teacher, a tutor for many years it was great to observe and compare 
the role of a teacher and the learner in online learning [13; 15], developing process of new skills and competences and challenges (table 2).

Table 2

Teacher and the learner role in online learning

\begin{tabular}{|c|l|l|l|}
\hline № & \multicolumn{1}{|c|}{ Teachers role } & \multicolumn{1}{|c|}{ Learner role } & \multicolumn{1}{c|}{ Skills/competences } \\
\hline & $\begin{array}{l}\text { To be aware of the differences between online } \\
\text { and face-to-face contexts; } \\
\text { - to build a positive learning environment and } \\
\text { welcome the students to the course; } \\
\text { - to help with technical issues; } \\
\text { - to maintain learners motivation; } \\
\text { - to maintain access all of the materials the } \\
\text { learners need to start learning; } \\
\text { - to learn the basics of how to communicate } \\
\text { online through the forums, the discussions; } \\
\text { - to know how to implement Moodle and online } \\
\text { learning; } \\
\text { - to develop the ways Moodle teaches. }\end{array}$ & $\begin{array}{l}\text { - To be able to access the } \\
\text { platform; } \\
\text { - to use computers for } \\
\text { learning; } \\
\text { - to produce more language } \\
\text { overall than students in a } \\
\text { face-to-face environment } \\
\text { (utterances with richer } \\
\text { vocabulary and sentence } \\
\text { structure); } \\
\text { - to tend to notice their } \\
\text { linguistic errors. }\end{array}$ & $\begin{array}{l}\text { - To use of digital information; } \\
\text { - to be able to manage, manipulate, collect, } \\
\text { understand and analyse digital information; } \\
\text { - to make reasonable decisions in the } \\
\text { future; } \\
\text { the create digital solutions and to make } \\
\text { - to handle and manage information; } \\
\text { - to interact with each other (online } \\
\text { socialisation); } \\
\text { - to be a coordinator and an academic } \\
\text { management. }\end{array}$ \\
\hline 2 & $\begin{array}{l}\text { To organize real-time communication; to record, } \\
\text { go back and watch a recording, and record } \\
\text { yourself. }\end{array}$ & $\begin{array}{l}\text { To record, go back and watch } \\
\text { a recording, and record } \\
\text { yourself. }\end{array}$ & \\
\hline
\end{tabular}

Professionals responsible for teaching and learning in today's society must be increasingly knowledgeable about using technology in practice [10]. The researchers of teaching online and teaching face-to-face highlight some features of these different kinds of teaching (table 3).

Table 3

Teaching online vs teaching face-to-face (by Cecilia Nobre)

\begin{tabular}{|c|c|c|c|}
\hline № & Skills & Online teaching & Face-to-face teaching \\
\hline 1 & $\begin{array}{l}\text { Communi-cation } \\
\text { skills }\end{array}$ & $\begin{array}{l}\text { To develop a wide range of communication skills; } \\
\text { to build an extra sense of patience and empathy; }\end{array}$ & $\begin{array}{l}\text { To impose voice and body language in a } \\
\text { confident caring manner }\end{array}$ \\
\hline 2 & $\begin{array}{l}\text { Time management } \\
\text { skills }\end{array}$ & $\begin{array}{l}\text { To plan lessons not long; } \\
\text { to teach different skills in the same lesson to add } \\
\text { dynamism; } \\
\text { to commute to students' homes, to use to spend hours } \\
\text { commuting being free from timetable; }\end{array}$ & $\begin{array}{l}\text { To limit the teacher's working hours due } \\
\text { to the travelling time most teachers need to } \\
\text { add to their routine. }\end{array}$ \\
\hline 3 & $\begin{array}{l}\text { Organisational } \\
\text { skills }\end{array}$ & $\begin{array}{l}\text { To organise teaching files (flashcards, lesson plans, } \\
\text { handouts, videos, exercises etc.) in a digital folder-- } \\
\text { digital library; } \\
\text { to use Google Drive to save files for sharing with } \\
\text { students; }\end{array}$ & $\begin{array}{l}\text { To carry paper books, flashcards, lesson } \\
\text { plans; } \\
\text { to organise materials properly; }\end{array}$ \\
\hline 4 & Computer skills & $\begin{array}{l}\text { To know how to use the webcam and its features; virtual } \\
\text { learning platform; }\end{array}$ & $\begin{array}{l}\text { To adopt a coursebook to be used with } \\
\text { their students; }\end{array}$ \\
\hline 5 & Assessing students & $\begin{array}{l}\text { To evaluate a student's proficiency level, needs and } \\
\text { learning preferences through a needs analysis (a Google } \\
\text { Form and an online interview); }\end{array}$ & $\begin{array}{l}\text { Face-to-face interview, questionnaire to be } \\
\text { filled in; } \\
\text { to sit a placement test. }\end{array}$ \\
\hline 6 & Social media & $\begin{array}{l}\text { To connect and interact with other like-minded teachers } \\
\text { from their home country or worldwide [17]. }\end{array}$ & $\begin{array}{l}\text { To join Facebook groups or Twitter to } \\
\text { interact with other teachers. }\end{array}$ \\
\hline
\end{tabular}

Among the key skills for online teacher we summarize the next: setting clear learning goals; planning every step; good management skills - to adapt the teaching techniques, used in the face-to-face classroom, in the digital environment; building rapport - setting up tasks, clear instructions and demonstrations of activities, checking learners have understood the tasks; using gestures - to invite learners to speak, to show learners that teacher's listening or waiting for them to speak; bringing energy to an online lesson. There are five effective ways to market yourself as an online teacher: set up a website with core message; be a Facebook expert; email or message former students if they want to try online lessons.

Conclusion. In conclusion we can say that language learning process has changed because the skills and content of any modern language course, the nature of assessment, impact of technology have changed. We used online platform resources for supporting our students' thinking about their language learning; helping them to understand the central aim of language learning; teaching them how to assess themselves; increasing the learners' motivation; using European standards of proficiency (the CECR levels).

\section{References:}

1. Міхненко Г. Е. Realization of blended learning ideas in teaching english for specific purposes. Наукові записки Наиіонального університету «Острозька академія»: серія «Філологія». Острог : Вид-во НаУОА, 2018. Вип. 1(69), ч. 2. С. $32-34$.

2. Самойленко Н. Б. Language portfolio: students' autonomous learning and language learning achievement. Scientific Letters of Academic Society of Michal Baludansky. Slovakia, 2018. Vol. 3. № . 6. P. 124-130.

3. Самойленко Н. Б. Language assessment: impact on teaching and learning cycle. Наукові записки Національного університету «Острозька академія»: Серія «Філологія». Острог : Вид-во НаУОА, 2018. Вип. 1(69). Ч. 2. С. 139-144. 
4. Самойленко Н.Б. Using English as a lingua franca: teaching and learning languages. Наукові досягнення, відкриття та шляяи розвитку педагогічної науки: матеріали Всеукраӥнської науково-практичної конференції, м. Запоріжжя, 25-26 травня 2018 р. Запоріжжя: Класичний приватний університет, 2018. С. 68-70.

5. Baker W. English as an academic lingua franca and intercultural awareness: student mobility in the transcultural university Language and Intercultural Communication [Electronic Resource]. Mode of access: http://www.tandfonline.com/doi/full/10.1080/14708477.2016.11 68053. (accessed 22 August 2018).

6. CEFR Companion volume with New Descriptors [Electronic Resource]. Mode of access: https://www.coe.int (accessed 22 February 2018).

7. Cogo A., Martin D. Analysing English as a Lingua Franca: A Corpus - Driven Investigation. New York: Continuum, 2012. P. $169-183$.

8. Connecting the 4 Cs of 21st Century Education (With a 5th C!) [Electronic Resource]. Mode of access: (accessed 19 July 2018)

9. Fifty Ways to Teach Online: Tips for ESL/EFL Teachers Paperback - December 30, 2016. 240 p.

10. Innovations in learning technologies for English language teaching/ Gary Motteram// British Council 2013, Brand and Design/ C60710 Spring Gardens London SW1A 2BN, UK.- 201 p. (www.britishcouncil.org)

11. Jenkins J. Global Englishes. A resource book for students. Abingdon, GB: Routledge, 3rd edition, 2015. 288 p.

12 Jenkins J. The future of English as a Lingua Franca? The Routledge Handbook of English as a Lingua Franca, Routledge, Editors: Jennifer Jenkins, Will Baker, Martin Dewey - Routledge, 2017. P. 594-605.

13. Ko S., Rossen S. Teaching Online. London: Routledge, 2010. 472 p.

14. Mauranen A. Second Language Acquisition, world Englishes, and English as a Lingua Franca (ELF). World Englishes, Mar. 2018 $-37,1$. P. 106-119.

15. Salmon G. E-Moderating: The Key to Teaching and Learning Online, 3rd edition. London: Kogan Page, 2011. 180 p.

16. Seidlhofer B. Understanding English as a Lingua Franca B. Seidlhofer. Oxford : Oxford University Press, 2011. P. 196-198.

17. Teaching Online Vs Teaching Face to Face [Electronic Resource]. Mode of access: https://ugc.futurelearn.com/uploads/files/fb/27/ fb27e68e-f9e0-4e4d-a7be-fbc7c08705df (accessed 17 August 2018).

18. The University of Southampton [Electronic Resource]. Mode of access: https://www.southampton. ac.uk/m1/ about/ staff/ wmlb. page. (accessed 18 August 2018).

19. Understanding languages : learning and teaching [Electronic Resource]. Mode of access: https://www.futurelearn.com/courses/ understanding-language/0/steps/21196. (accessed 27 August 2018).

20. Wen Q. English as a lingua franca [Electronic Resource]. A pedagogical perspective. Journal of English as a Lingua Franca. 2012 - 1(2). P. 371-376. Mode of access: https://doi.org/10.1515/jelf-2012-0024 (accessed 27 August 2018). 